\title{
ANALISIS BIOINFORMATIKA DAN EKSPRESI PROTEIN REKOMBINAN HEMAGGLUTININ DOMAIN GLOBULAR DARI VIRUS H5N1 INDONESIA PADA Escherichia coli BL21 (DE3) SEBAGAI KOMPONEN VAKSIN SUBUNIT INFLUENZA
}

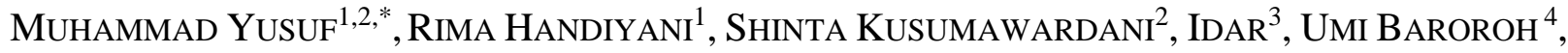 \\ DAN TOTO SUBROTO ${ }^{1,2}$
}

\author{
${ }^{1}$ Departemen Kimia, Fakultas Matematika dan Ilmu Pengetahuan Alam, Universitas Padjadjaran, \\ Jalan Raya Bandung Sumedang KM 21, Sumedang, Jawa Barat, Indonesia \\ ${ }^{2}$ Pusat Riset Bioteknologi Molekuler dan Bioinformatika, Universitas Padjadjaran, \\ Jalan Singaperbangsa No. 2, Bandung, Jawa Barat, Indonesia \\ ${ }^{3}$ Fakultas Farmasi, Universitas Bhakti Kencana, \\ Jl. Soekarno Hatta No. 754, Bandung, Jawa Barat, Indonesia \\ ${ }^{4}$ Departemen Bioteknologi Farmasi, Sekolah Tinggi Farmasi Indonesia, \\ Jl. Soekarno Hatta No. 354, Bandung, Jawa Barat, Indonesia \\ *alamat email korespondensi: m.yusuf@unpad.ac.id
}

\begin{abstract}
Informasi Artikel
Riwayat Naskah :

Diterima pada 14

September 2021

Diterima setelah

direvisi pada 24

Desember 2021

Diterbitkan pada 31

Desember 2021
\end{abstract}

\section{Kata Kunci:}

Bioinformatika;

influenza;

hemagglutinin; protein rekombinan; vaksin; Escherichia coli.

\section{Keywords:}

Bioinformatics; influenza; hemagglutinin; recombinant protein; vaccine; Escherichia coli.

\section{Abstrak/Abstract}

Flu burung merupakan salah satu penyakit zoonosis yang patut diwaspadai di Indonesia, khususnya galur High Pathogenic Avian Influenza (HPAI) karena dapat mematikan jika menular kepada manusia. Penggunaan vaksin influenza pada unggas, merupakan langkah preventif terhadap evolusi virus yang berbahaya dan juga penyebarannya. Selama ini, Indonesia masih menggunakan seed vaksin impor yang berasal dari luar Indonesia. Namun, karena Indonesia merupakan negara yang berada di garis khatulistiwa, karakteristik virus bisa berbeda dengan virus dari nothern-hemispere maupun southern-hemispere. Mengingat hal tersebut, Indonesia harus mengembangkan vaksin influenza menggunakan galur virus lokal. Berbeda dengan vaksin whole virus, vaksin rekombinan memiliki keunggulan dari sisi kemurnian, kecepatan produksi, dan kesesuaian galur terhadap virus yang beredar saat diperlukan. Penelitian ini bertujuan untuk menganalisis sekuen hemagglutinin (HA) Indonesia dengan strain lainnya serta mengekspresikkan protein HA1 rekombinan pada Escherichia coli BL21 (DE3). Galur yang digunakan pada studi ini berasal dari virus H5N1 (A/Indonesia/05/05), khususnya bagian domain globular dari HA1. Sekuen HA1 bervariasi antara strain Indonesia dengan nothern-hemispere maupun southern-hemispere dan merupakan protein yang terpapar ke luar virus. Gen HA1 disisipkan pada vektor pET-28a, kemudian plasmid diisolasi menggunakan meoe manniatis, setelah itu diekspresikan dengan induksi 1 mM IPTG selama 4 jam. Protein HA1 telah berhasil diekspresikan secara intraseluler dan telah dikonfirmasi pada berat molekul $40 \mathrm{kDa}$ menggunakan SDS-PAGE. Penelitian ini dapat digunakan untuk mengembangkan vaksin subunit yang lebih spesifik terhadap virus yang beredar di lapangan.

Avian influenza is one of the most dangerous zoonotic diseases in Indonesia, especially the High Pathogenic Avian Influenza (HPAI) strain because it can be lethal when infecting a human. The use of the influenza vaccine for birds is a preventive effort to the evolution of the virus and its spread. Until now, Indonesia is still using the imported vaccine seed from abroad. Nevertheless, due to the location of Indonesia on the equatorial, thus the circulating local virus is having different characteristics from that of the northern and southern hemispheres. For this reason, Indonesia should start developing vaccines from the local strain. Different from the whole virus vaccine, the recombinant vaccine has advantages in many aspects, such as purity, time-efficiency, and match to the circulating strain of virus. This study aimed to analyze the hemagglutinin (HA) sequence of Indonesia to the others strains and to produce the globular domain of recombinant HA1 using Escherichia coli BL21 (DE3) expression system. The strain used in this study was H5N1 (A/Indonesia/05/05), particularly the globular domain of HA1. The gene of HAl was inserted into the vector pET-28a, then it was expressed by $1 \mathrm{mM}$ IPTG inducer for 4 hours. HAl protein was successfully expressed intracellularly and confirmed the molecular weight of $40 \mathrm{kDa}$ by SDS-PAGE. This study should be useful in developing subunit vaccines that are more specific to viruses circulating in the field. 


\section{PENDAHULUAN}

Avian Influenza (AI) atau disebut juga flu burung adalah penyakit infeksi yang menyerang unggas, seperti ayam peliharaan, kalkun, bebek, burung puyuh, dan angsa. Virus ini merupakan anggota famili Orthomyxoviridae [1, 2]. Meskipun demikian, flu burung juga mengancam kesehatan manusia. Virus AI H5N1 telah ditemukan dapat menular pada manusia, dan hal ini pertama kali dilaporkan di Hong Kong [3]. Virus flu burung H5 dan H7 High Pathogenic Avian Influenza (HPAI) yang ditularkan ke manusia dari unggas berasal dari terjadinya proses reassorment (bercampurnya materi genetik virus influenza pada hewan dan manusia) sehingga dalam perkembangannya penyakit flu burung tidak hanya menyerang unggas, tetapi juga dapat menyerang manusia $[4$, 5]. Virus HPAI subtipe H5N1 telah menyebabkan wabah di beberapa negara seperti Kamboja, Laos, Myanmar, Indonesia, Thailand, dan Vietnam [6]. Vaksin merupakan salah satu upaya yang penting untuk menanggulangi patogen berbahaya seperti virus HPAI. Vaksin sebaiknya dibuat berdasarkan jenis virus yang beredar di lapangan saat terjadi endemi atau bahkan pandemi. Jika strain virus influenza yang beredar berbeda dengan virus yang terkandung dalam vaksin, maka cakupan perlindungan dari vaksin menjadi kurang efektif [7]. Berdasarkan rekomendasi WHO, formulasi vaksin Influenza yang digunakan dibagi menjadi dua daerah yaitu northern dan southern hemisphere. Daerah nothern hemisphere formulasinya harus mencerminkan strain virus yang diperkirakan akan beredar didaerah tersebut, begitupun dengan daerah southern hemisphere [8]. Indonesia tepat berada pada garis khatulistiwa, yang memungkinkan Indonesia memiliki karakteristik virus influenza yang khas. Saat ini, kebanyakan vaksin influenza yang beredar di Indonesia masih menggunakan seed vaksin impor [9].

Berbeda dengan vaksin berbasis virus utuh (whole virus vaccine) dan vaksin inaktif, vaksin subunit hanya mengandung protein permukaan dari virus dan memiliki reaktogenisitas yang rendah [10]. Hemaglutinin (HA) merupakan salah satu dari protein permukaan virus influenza yang bersifat imunogenik dan dapat diproduksi sebagai protein rekombinan. Protein HA terdiri dari domain HA1 dan HA2 yang ditampilkan pada permukaan partikel virus dan memiliki kemampuan untuk berinteraksi dengan reseptor glikan di permukaan sel inang. HA juga dapat dinetralisasi dengan antibodi, sehingga berpotensi untuk digunakan sebagai komponen vaksin [11]. Saat ini, vaksin H1N1 berbasis HA rekombinan (rHA) telah berhasil diproduksi di sel serangga, dan telah dikomersialisasikan dengan merk dagang FluBlok [12]. Untuk meningkatkan jumlah produksi dari rHA dalam bentuk rekombinan aktif dan fungsional melalui sistem ekspresi prokariotik, inang Escherichia coli memungkinkan produksi lebih mudah dan dengan biaya lebih rendah dibandingkan dengan platform ekspresi lainnya [11, 13-15]. Menariknya, eskpresi domain HA1 saja, tanpa HA2, ternyata dapat menghasilkan respon imunitas yang sama dengan protein dengan ukuran utuh (HA1 dan HA2) [7, 16-18]. Ekspresi protein HA1 pada sistem bakteri dapat menjadi alternatif metode yang cepat dan ekonomis untuk mengembangkan vaksin influenza yang sesuai dengan strain virus di lapangan [19]. Saat ini, kemajuan bioinformatika juga dapat dimanfaatkan untuk menganalisis gen dan protein virus yang berasal dari varian lokal. Oleh karena itu, penelitian ini bertujuan untuk menganalisis sekuen HA dari virus $\mathrm{H} 5 \mathrm{~N} 1$ yang beredar di Indonesia, serta mengekspresikan protein rHA domain HA1 pada sistem Escherichia coli BL21 (DE3). Diharapkan penelitian ini dapat berkontribusi pada pengembangan vaksin subunit untuk menanggulangi penyakit yang beredar di Indonesia pada khususnya, serta regional dan global pada umumnya.

\section{EKSPERIMEN}

\section{Material}

Untuk analisis bioinformatika digunakan sekuen asam amino protein HA yang diperoleh dari database influenza pada website NCBI (https://www.ncbi.nlm.nih.gov/genomes/FLU/Dat abase) dan struktur protein HA dengan kode PDB 6NTF (https://www.rcsb.org), sedangkan untuk ekspresi protein bahan-bahan yang digunakan adalah bakteri Escherichia coli BL21(DE3) kosong, sequence HA1 A/Indonesia/05/05 strain H5N1 dalam plasmid pET28a (disintesis oleh GENERAY dan dioptimasi oleh GENSCRIPT), plasmid pG-Tf3, kit isolasi plasmid (TIANprep Mini Plasmid Kit), enzim BamHI, enzim XhoI, loading dye (Thermo Scientific), Primer sekuensing $\mathrm{T} 7$ promoter dan primer $\mathrm{T} 7$ terminator, serta marka DNA 1 kb Ladder (Thermo Scientific).

\section{Instrumentasi}

Program yang digunakan untuk analisis bioinformatika dalam penelitian ini adalah Influenza Virus Database (https://www.ncbi.nlm.nih.gov/genomes/FLU/Dat abase), Ellipro (http://tools.iedb.org/ellipro/), dan 
BIOVIA Discovery Studio 2017, sedangkan perangkat keras yang digunakan adalah personal computer (PC) dengan spesifikasi processor Intel(R) Core (TM) i5-8250U CPU @ 1.60GHz $1.80 \mathrm{GHz}$, memory $8 \mathrm{~GB}$ RAM, harddisk 320GB, dan GPU NVIDIA GE FORCE 940 MX.

Instrumen yang digunakan untuk ekspresi protein yaitu autoclave sterilizer, elektroporator, kuvet, magnetic stirrer, $\mathrm{pH}$ meter, neraca timbang, sentrifugator, tabung falcon, vortex, inkubator goyang, pipet mikro, tabung mikro, sonikator, elektroforesis gel agarosa dan SDS-PAGE (Biorad Power PacTM Basic), serta AIV Ag kit (Bionote).

\section{Prosedur}

\section{Analisis Bioinformatika Protein HA dari Virus H5N1}

Sekuen protein HA diperoleh dari Influenza Virus Resource yang tersedia pada website NCBI. Sekuen HA tersebut diperoleh dengan memasukkan pencarian tipe A, inang avian, negara Indonesia/daerah northern/southern-hemispere, protein HA, subtipe H5N1, dan panjang sekuen 500-600 asam amino. Hasil pencarian kemudian dilakukan penyejajaran sekuen sehingga diperoleh konsensus sekuen Indonesia, northern, dan southern-hemispere. Ketiga konsensus sekuen tersebut kemudian dibandingkan dan dipetakan ke dalam struktur protein HA.

Prediksi epitope sel B dilakukan pada program Ellipro (http://tools.iedb.org/ellipro/) dengan menginput struktur HA dengan kode PDB $6 \mathrm{NTF}$.

Konstruksi Plasmid pET28a-HA1 dan transformasi Escherichia coli BL21(DE3) dengan Plasmid pET28a-HAl

Urutan gen HA1 yang mengkode asam amino dari virus $\mathrm{H} 5 \mathrm{~N} 1$ galur $\mathrm{A} / \mathrm{Indonesia} / 05 / 05$ (AFM78567.1) dioptimasi sesuai dengan preferensi kodon Escherichia coli BL21 (DE3). Sisi pemotongan enzim restriksi BamHI dan XhoI ditambahkan ke ujung 5 'dan 3' dari gen sintetis. Urutan gen sintetis disisipkan ke dalam plasmid ekspresi pET28a (+) linier, menghasilkan plasmid pET28a-HA1. Plasmid pET28a-HA1 memiliki marker seleksi antibiotik kanamisin dan His-tag di ujung $\mathrm{N}$ dan $\mathrm{C}$.

Plasmid pET28a-HA1 ditransformasikan ke dalam Escherichia coli BL21 (DE3) dengan metode elektroporasi pada tegangan $1500 \mathrm{mV}$. Transforman diseleksi pada pelat agar LB yang mengandung $100 \mu \mathrm{g} / \mathrm{ml}$ kanamisin.

\section{Isolasi dan Karakterisasi pET28a-HAI}

Transforman pET28a-HA1 ditumbuhkan dalam $5 \mathrm{~mL}$ LB (Luria Bertani) cair yang mengandung $100 \mu \mathrm{g} / \mathrm{mL}$ kanamisin. Kemudian, plasmid diisolasi menggunakan metode Manniatis. Hasil isolasi plasmid dikarakterisasi dengan metode sekuensing dan pemotongan enzim restriksi. Plasmid yang dipotong dengan satu enzim akan menghasilkan plasmid yang linier, sedangkan plasmid yang dipotong menggunakan dua enzim akan menghasilkan insert gene dan backbone.

Komposisi pemotongan plasmid oleh satu enzim restriksi yang digunakan yaitu: $1 \mu \mathrm{g}$ isolat plasmid, 10 unit enzim restriksi, buffer cut smart dengan konsentrasi akhir 1x, dan NFW (nuclease free water) hingga volume total $50 \mu \mathrm{L}$. Komposisi pemotongan plasmid oleh dua enzim retriksi yaitu: $1 \mu \mathrm{g}$ isolat plasmid, 10 unit enzim restriksi BamHI, 10 unit enzim restriksi xhoI, buffer cut smart hingga konsentrasi akhir 1x, dan NFW hingga total volume $50 \mu \mathrm{L}$. Kemudian, semuanya diinkubasi selama tiga jam pada suhu $37^{\circ} \mathrm{C}$ dan divisualisasi hasil restriksinya menggunakan gel agarosa $1 \%$ dengan $1 \mathrm{~Kb}$ DNA Ladder.

\section{Ekspresi Protein HAl}

Koloni tunggal yang mengandung plasmid ekspresi pET28a-HA1 ditumbuhkan pada media 5 $\mathrm{mL}$ LB cair yang mengandung $100 \mu \mathrm{g} / \mathrm{mL}$ kanamisin pada $37^{\circ} \mathrm{C}$ dengan aerasi konstan semalaman sebagai kultur starter. Kultur starter 5\% diencerkan dalam $10 \mathrm{~mL}$ media $\mathrm{LB}$ cair yang mengandung $100 \mu \mathrm{g} / \mathrm{mL}$ kanamisin. Ketika kultur mencapai fase pertengahan log (panjang gelombang $600 \mathrm{~nm}$ OD $_{600} 0,4-0,6$ ), ekspresi protein rekombinan diinduksi oleh $1 \mathrm{mM}$ IPTG dan diinkubasi pada variasi waktu induksi selama 3, 6, dan 18 jam pada $37^{\circ} \mathrm{C}$. Kultur dipanen dan pelet diresuspensi dengan buffer lisis 1x PBS pH 7,4. Pelet dilisis dengan metode sonikasi selama 5 detik On dan 5 detik Off selama 25 menit pada daya 30\%. Kemudian, sentrifugasi dilakukan untuk memisahkan fraksi yang dapat larut dan tidak larut pada 10,0000 x g selama 20 menit pada $4^{\circ} \mathrm{C}$. Pelet yang merupakan fraksi tidak larut diresuspensi dalam Urea $8 \mathrm{M}$, dan dipanaskan pada suhu $95^{\circ} \mathrm{C}$ selama 15 menit sampai larut. Fraksi larut dan tidak larut dianalisis dengan elektroforesis sodium dodecyl sulfate-polyacrilamide gel (SDS-PAGE) dengan menggunakan gel poliakrilamida $10 \%$. Protein dideteksi dengan pewarnaan Coomassie briliant blue. 


\section{HASIL DAN PEMBAHASAN}

\section{Analisis Bioinformatika Protein HA dari Virus H5N1 lokal}

Hasil pencarian menunjukkan bahwa sekuen protein HA tersedia 229 sekuen Indonesia tanpa pengulangan dengan total 364 sekuen. Sekuen northern-hemispere tersedia 529 sekuen tanpa pengulangan dengan total 809 sekuen, sedangkan untuk sekuen southern-hemispere hanya ada 1 sekuen yang berasal dari Afrika Selatan (https://www.ncbi.nlm.nih.gov/genomes/FLU/Dat abase).

Konsensus sekuen dari masing-masing wilayah disejajarkan dan menunjukkan bahwa sekuen Indonesia memiliki persentase 96,8\% dan $90,7 \%$ identik, masing-masing terhadap konsensus sekuen northern dan southern-hemispere. Hasil penyejajaran ditampilkan pada Gambar 1.

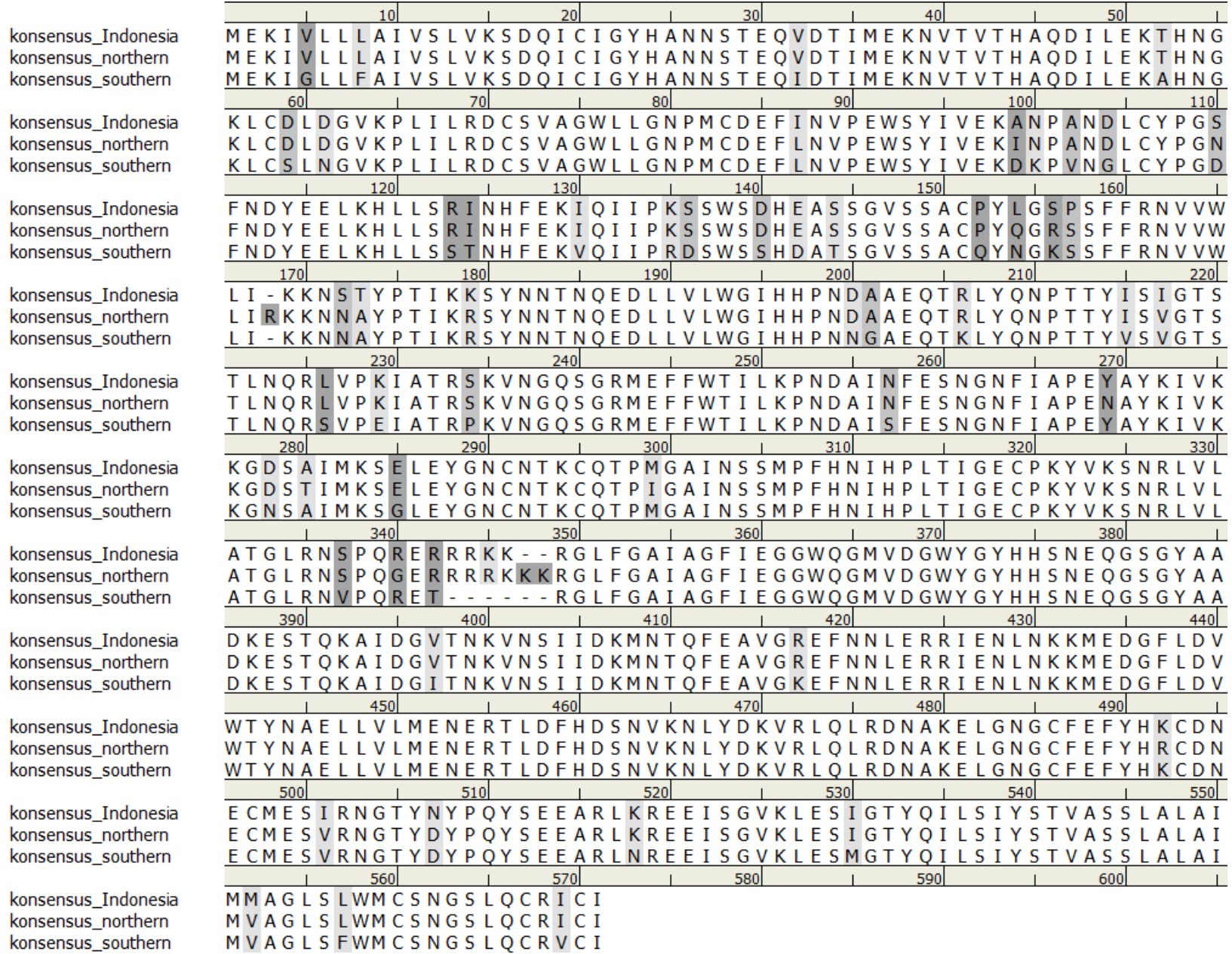

Gambar 1. Penyejajan sekuen konsensus Indonesia dengan sekuen northern dan southern-hemispere.

Dari ketiga sekuen tersebut, perbedaan asam amino banyak terjadi pada daerah HA1 (urutan 1348). Hal ini menyebabkan pengembangan vaksin strain lokal penting dilakukan. Protein HA adalah protein di permukaan virus yang mampu mengaktifkan respon imun dan memiliki respon yang spesifik terhadap subtipe virus [20]. Protein HA juga merupakan protein yang menjadi faktor penentu patogenisitas dan memiliki peran penting pada interaksi dengan reseptor sel inang [21]. Karena posisinya yang berada di permukaan virus, protein HA mudah mengalami mutasi. Ketika dipetakan ke dalam struktur, perbedaan asam amino pada ketiga wilayah terjadi di bagian terluar virus, terutama pada HA1 (Gambar 2). Berdasarkan hasil prediksi epitope sel B pada struktur HA juga menunjukkan bahwa varian asam amino berada di bagian epitope. Selain itu, prediksi epitope juga menunjukkan bahwa HA1 lebih imunogenik dibandingkan HA2. Hal ini terjadi karena HA2 terletak di bagian antara monomermonomer HA dan tidak terekspos ke permukaan virus. Oleh karena itu, ekspesi HA1 saja HA1 saja mampu menghasilkan respon imunitas yang sama dengan protein dengan ukuran utuh [7, 16, 18-19]. 


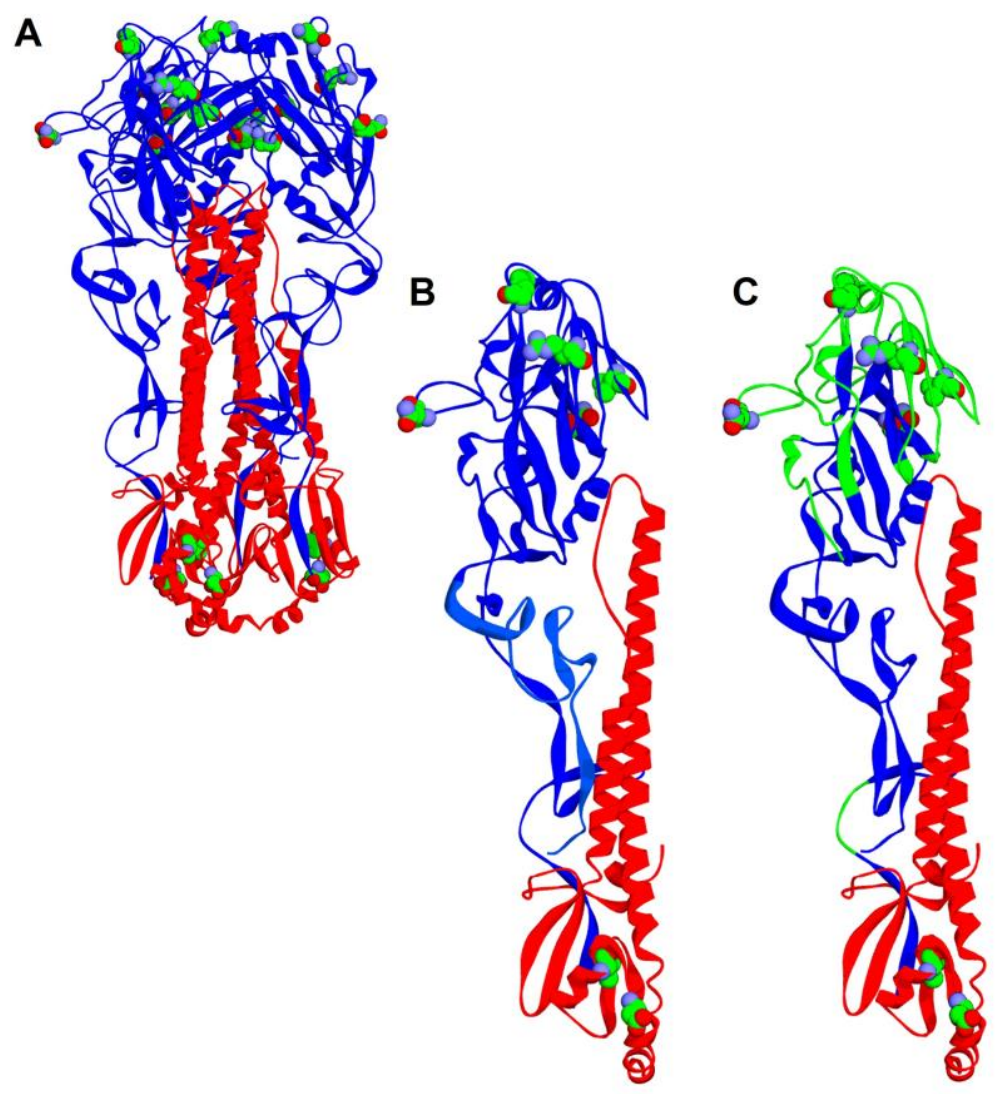

Gambar 2. A) Struktur HA dalam keadaan trimer. HA1 digambarkan dengan warna biru, HA2 digambarkan dengan warna merah, dan perbedaan asam amino digambarkan dengan bentuk CPK berwarna hijau, B) Struktur monomer HA, dan C) struktur monomer HA dengan daerah epitope berwarna hijau.

\section{Transformasi [pET28a(+)-HA1] pada Escherichia coli BL21 (DE3)}

Transformasi sel inang menggunakan plasmid rekombinan merupakan salah satu metode untuk menyisipkan material genetik ekternal yang berupa fragmen DNA, baik DNA kromosom maupun DNA plasmid ke dalam sel. Vektor rekombinan pET28a(+)-HA ditransformasikan ke dalam sel kompeten Escherichia coli BL21 (DE3) dengan menggunakan elektroporasi. Teknik elektroporasi berfungsi untuk meningkatkan efisiensi transformasi DNA rekombinan ke dalam sel inang. Kejutan listrik menyebabkan pembentukan pori sementara pada membran sel inang, sehingga DNA dapat masuk kemudian poripori membran sel akan menutup kembali [22].

Proses transformasi pET28a-HA1 dikontrol dengan penggunaan antibiotik dan sel kompeten Escherichia coli BL21(DE3) sehingga didapatkan hasil yang benar dan terkonfirmasi. Kontrol positif adalah sel kompeten Escherichia coli BL21(DE3) yang harus tumbuh pada media LB padat tanpa antibiotik. Sel kompeten Escherichia coli BL21(DE3) melewati proses pencucian menggunakan akuades steril dingin berulang kali sehingga bebas garam. Kemampuan sel
Escherichia coli BL21(DE3) untuk hidup setelah melewati proses pembuatan sel kompeten di dalam media LB tanpa antibiotik diuji. Hasil menujukkan bahwa sel kompeten Escherichia coli BL21 dapat tumbuh dalam media LB padat (Gambar 2A). Sel Escherichia coli BL21(DE3) yang ditransformasi oleh plasmid pET28a-HA1 ditumbuhkan pada media LB padat yang mengandung $100 \mu \mathrm{g} / \mathrm{mL}$ kanamisin. Hasil menujukkan proses transformasi telah berhasil. Transforman Escherichia coli BL21(DE3) dapat tumbuh pada media LB padat dengan $100 \mu \mathrm{g} / \mathrm{mL}$ kanamisin karena plasmid pET28a-HA1 membawa gen resisten terhadap kanamisin (Gambar 2B), sedangkan, sel kompeten Escherichia coli BL21(DE3) sebagai kontrol negatif tidak dapat tumbuh pada media LB padat yang mengandung antibiotik karena tidak membawa plasmid yang resisten terhadap kanamisin (Gambar 2C).

\section{Isolasi dan Karakterisasi plasmid [pET28a(+)- HA1]}

Plasmid pET28a(+)-HA1 diisolasi dari transforman Escherichia coli BL21 pET28a(+)HA1 dan dikarakterisasi menggunakan enzim retriksi BamHI dan/atau XhoI. Hasil karakterisasi 
menunjukkan satu fragmen terbentuk ketika pET28a(+)-HA dipotong dengan enzim retriksi BamHI atau XhoI, dengan ukuran $6,3 \mathrm{~Kb}$ yang merupakan ukuran pET28a(+)-HA (Gambar 3, lajur 3 dan 4). Plasmid pET28a(+)-HA yang dipotong dengan dua enzim BamHI dan XhoI akan menghasilkan dua fragmen, pertama adalah Backbone plasmid pET28a(+) dan yang kedua merupakan fragmen $\mathrm{HA} 1$ yang berukuran $1,0 \mathrm{~Kb}$ (Gambar 3 lajur 2).

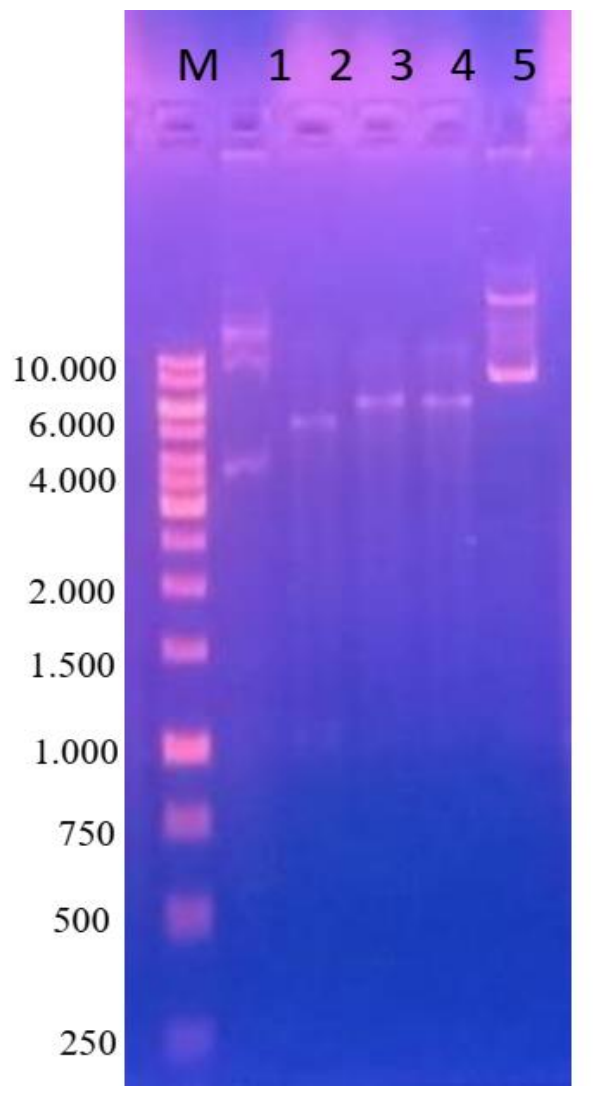

Gambar 3. Analisis hasil pemotongan plasmid pET28aHA1 menggunakan enzim retriksi BamHI dan XhoI. Marker $1 \mathrm{~Kb}$ (lajur M); Plasmid pET28a-HA1 uncut (lajur 1 dan 5); Plasmid pET28a-HA1 dipotong dengan BamHI dan XhoI (lajur 2); Plasmid pET28a-HA1 dipotong dengan BamHI (lajur 3); dan Plasmid pET28aHA1 dipotong dengan XhoI (lajur 4).

Analisis hasil sekuensing menunjukkan bahwa sekuen HA1 pada plasmid pET28a(+)-HA1 terkonfirmasi $100 \%$ identik (Gambar 4). Urutan nukleotida dari hasil sekuensing menggunakan primer T7 promoter dan T7 terminator direkonstruksi menjadi contig menggunakan program PRABI-Doua, kemudian disejajarkan dengan sekuen desain HA1 dengan program Clustal Omega (Gambar 3). Tidak terdapat perbedaan sekuen antara HA1 hasil sekuensing dengan desain, sehingga dapat digunakan untuk ekspresi protein rekombinan HA1 (rHA1) di Escherichia coli BL21(DE3).

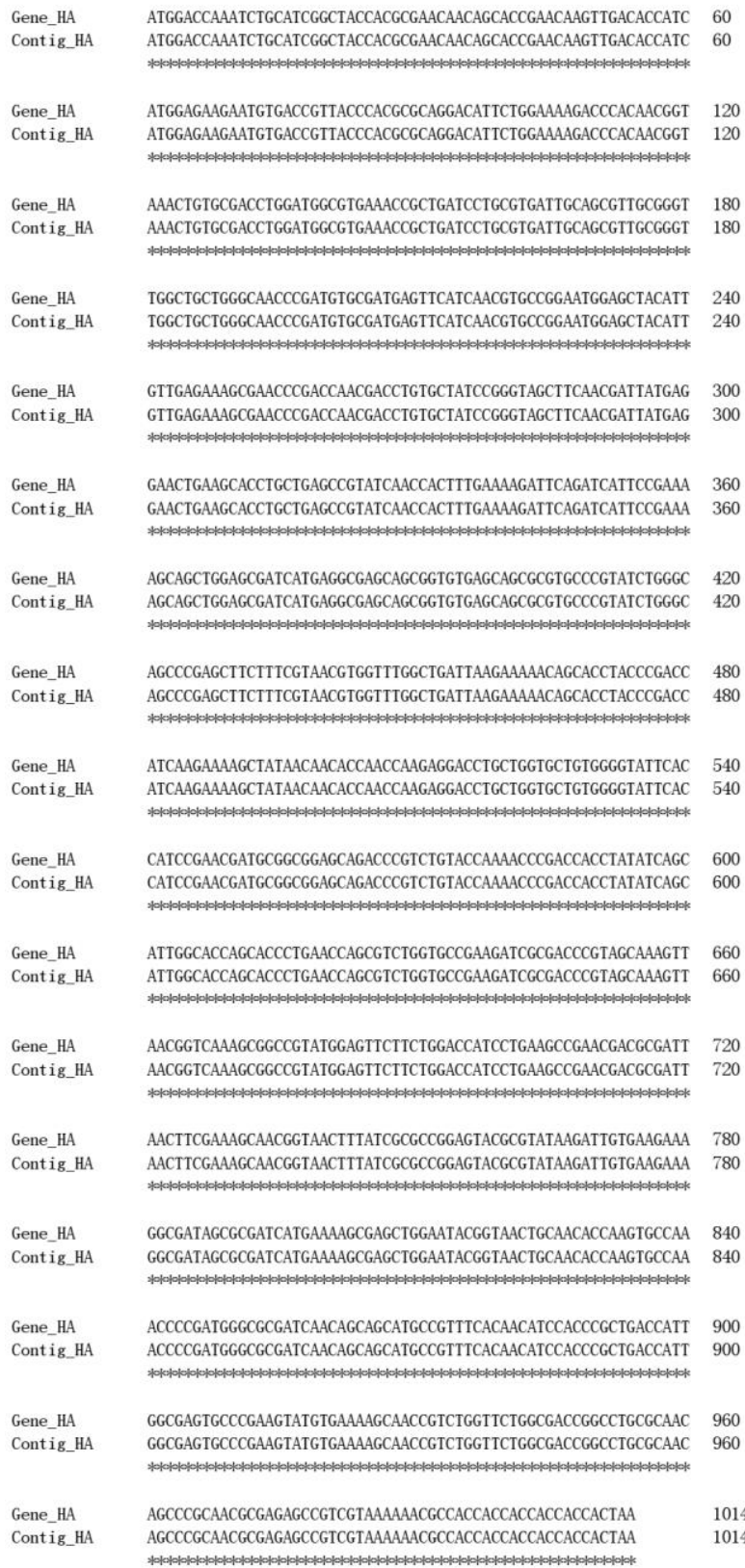

Gambar 4. Hasil pensejajaran Sekuen HA desain dengan contig HA menggunakan program Clustal OMega.

\section{Ekspresi protein HA1}

Struktur HA terdiri dari HA1 dan HA2. Bagian yang terpapar ke permukaan adalah HA1, sehingga bagian tersebut lebih immunogenik dibandingkan dengan HA2 (Gambar 2). Sehingga pada penelitian ini, HA1 dipilih sebagai kandidat vaksin influenza.

Protein rekombinan HA1 dapat diproduksi di sel mamalia, serangga, ragi, dan bakteri. Inang Escherichia coli BL21(DE3) dipilih karena dapat tumbuh dengan densitas yang tinggi sehingga menghasilkan protein dalam jumlah yang besar. Pertumbuhan Escherichia coli juga cepat sehingga waktu produksi protein rekombinan menjadi 
singkat. Selain itu, media pertumbuhan yang digunakan juga sederhana dan murah [23]. Beberapa penelitian sebelumnya telah berhasil memproduksi protein rekombinan HA dalam fraksi tidak terlarut.

Pada penelitian ini dilakukan produksi protein HA1 pada Escherichia coli BL21(DE3) menggunakan promoter T7. Promoter ini bekerja jika diinduksi oleh IPTG ( $\beta$-d-1thiogalactopyranoside), suatu alolaktosa (senyawa mirip laktosa) yang bertindak sebagai sumber nutrisi. IPTG tidak akan dipecah oleh metabolisme sel, sehingga jumlahnya tidak akan berkurang selama proses pertumbuhan bakteri dalam memproduksi protein target [24].

Tahap pertama, dilakukan ekspresi dengan konsentrasi IPTG $1 \mathrm{mM}$. Penelitian sebelumnya [12] menunjukkan bahwa konsentrasi IPTG $1 \mathrm{mM}$ dapat menghasilkan ekspresi protein HA yang lebih baik dibandingkan variasi konsentrasi lain $(0 ; 0,2$; 0,$4 ; 0,6$; dan $0,8 \mathrm{mM}$ ). Suhu yang digunakan untuk produksi rHA1 adalah $37^{\circ} \mathrm{C}$, sedangkan waktu induksi divariasikan pada 3, 6, dan 18 jam.

Hasil ekspresi yang dikarakterisasi menggunakan Glisin SDS-PAGE ditunjukkan pada Gambar 5. Dari hasil karakterisasi pada Gambar 5A terlihat bahwa protein HA1 berhasil diekspresikan. Namun, pita protein HA1 yang berada pada $40 \mathrm{kDa}$ nampak tipis dan sedikit menebal pada fraksi induksi jam ke-18. Sementara, pita HA1 pada fraksi tidak terlarut (Gambar 5B) pada jam ke-18 jauh lebih tebal dibandingkan pada fraksi terlarut. Hal ini menunjukkan bahwa protein HA1 masih dalam fraksi tidak terlarut yang membentuk badan inklusi (inclusion bodies).

Protein yang terekspresi sebagai badan inklusi diakibatkan proses pelipatan (folding) protein yang belum sempurna, sehingga membentuk agregat dan belum dalam konformasi struktur tersier yang belum aktif. Terdapat beberapa cara yang dapat dilakukan untuk meningkatkan kelarutan protein, diantaranya adalah optimasi desain gen yang akan diekspresikan agar menghasilkan mRNA yang stabil, ko-ekspresi dengan chaperon yang dapat memperbaiki pelipatan protein, mengoptimasi penggunaan media pertumbuhan yang dapat mempengaruhi produksi jumlah protein dan kelarutannya, serta menurunkan suhu pertumbuhan bakteri untuk menghindari interaksi hidrofobik antar protein.

Namun, menghasilkan protein sebagai badan inklusi (protein tidak terlarut) juga memiliki kelebihan. Diketahui bahwa proses pemurnian protein terlarut lebih sulit jika dibandingkan dengan protein tidak terlarut. Solubilisasi protein tidak terlarut masih menjadi pilihan yang lebih disukai dalam produksi protein rekombinan. Pada Gambar 5A, terlihat bahwa protein HA1 lebih banyak dihasilkan pada fraksi tidak terlarut. Oleh karena itu, protein HA1 dalam keadaan aktif dapat diperoleh melalui proses solubilisasi.

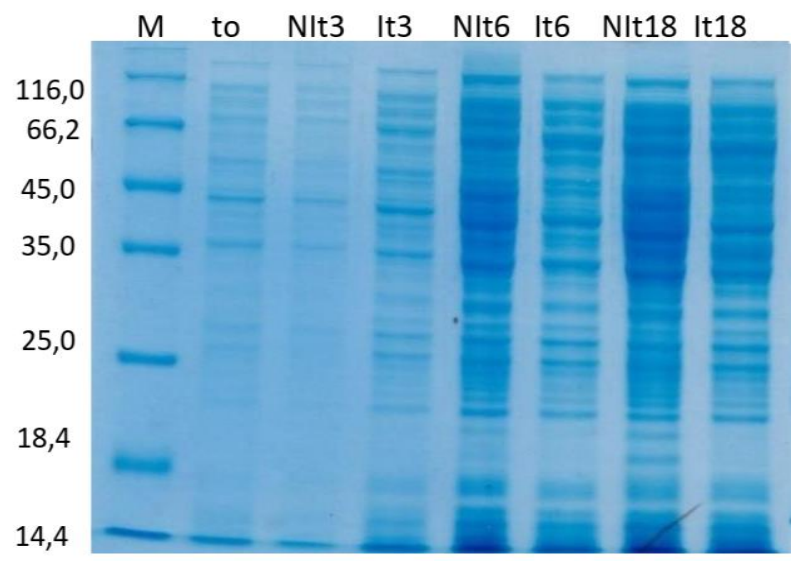

(A)



(B)

Gambar 5. Ekspresi HA1 pada transforman Escherichia coli BL21(DE3) dengan pET28a-HA1 yang diinduksi oleh IPTG pada suhu $37{ }^{\circ} \mathrm{C}$ dengan waktu T0, T3, T6, T18 pasa induksi. (A) Fraksi Terlarut/ soluble (S), (B) Fraksi tidak terlarut/ insoluble fraction (IF) (ket : NI : non induksi, I : Induksi).

Proses solubilisasi yang telah dilakukan adalah dengan menambahkan $8 \mathrm{M}$ Urea pada fraksi tidak terlarut dan menginkubasi pada suhu $95^{\circ} \mathrm{C}$ selama 15 menit. Urea akan mereduksi ikatan hidrogen pada agregat rHA1 sehingga dapat menjadi protein terlarut.

\section{SIMPULAN}

Analisis sekuen HA Indonesia, northern dan southern hemisphere menunjukkan perbedaan asam amino terjadi terutama di bagian HA1 dan merupakan daerah yang diprediksi sebagai epitope 
sel B. Protein HA1 rekombinan berhasil diekspresikan dengan kondisi induksi 1 mM IPTG pada suhu $37^{\circ} \mathrm{C}$. Hasil penelitian menunjukkan bahwa ekspresi optimal terjadi pada jam ke-18. Protein rHA1 lebih banyak dihasilkan dalam fraksi tidak terlarut sebagai badan inklusi. Langkah berikutnya yang dapat dilakukan adalah solubilisasi rHA1 menggunakan chaperone (in vivo) atau larutan kimia refolding (in vitro) untuk menghasilkan protein pada fraksi terlarut. Diharapkan solubilisasi protein HA1 akan menghasilkan stuktur dalam keadaan natif dan imunogenik, sehingga dapat digunakan sebagai komponen vaksin subunit influenza.

\section{UCAPAN TERIMA KASIH}

Kami mengucapkan terima kasih kepada Kemenristekdikti yang telah mendanai kegiatan ini melalui skema PPTI dan mitra industri PT. Tekad Mandiri Citra.

\section{REFERENSI}

[1] S.V. Vemula, J. Zhao, J. Liu, X.W. Xue, S. Biswas, and I. Hewlett, "Current approaches for diagnosis of influenza virus infections in humans", Viruses, vol. 8, no. 4, pp. 1-15, 2016.

[2] A. Mostafa, E.M. Abdelwhab, T.C. Mettenleiter, and S. Pleschka, "Zoonotic potential of influenza A viruses: A comprehensive overview", Viruses, vol. 10, no. 9, pp. 1-38, 2018.

[3] WHO, "Avian Influenza Weekly Update Number 474 Human infection with avian influenza A ( H5 ) viruses Human infection with avian influenza A ( H7N9 ) virus in China", no. 474, pp. 7-9, 2015.

[4] S.J. Lycett, F. Duchatel, and P. Digard, "A brief history of bird flu", Philosophical Transactions of The Royal Society B Biological Sciences, vol. 374, no. 1775, pp. 03, 2019.

[5] N.R. da S. Martins, "An overview on Avian influenza", Revista Brasileira de Ciencia Avicola, vol. 14, no. 2, pp. 71-87, 2012.

[6] D. Eagles, E.S. Siregar, D.H. Dung, J. Weaver, F. Wong, and P. Daniels, "H5N1 highly pathogenic avian influenza in Southeast Asia", OIE Revue Scientifique et Technique, vol. 28, no. 1, pp. 341-348, 2009.

[7] K. Tonegawa, E. Nobusawa, K. Nakajima, T. Kato, T. Kutsuna, et al., "Analysis of epitope recognition of antibodies induced by DNA immunization against hemagglutinin protein of influenza A virus", Vaccine, vol. 21, no. 23, pp. 3118-3125, 2003.

[8] N. Cox, "Influenza seasonality: timing and formulation of vaccines", Bulletin World Health Organ., vol. 92, no. 5, pp. 311, 2014.

[9] M. Suhardono, D. Ugiyadi, I. Nurnaeni, and I. Emelia, "Establishment of pandemic influenza vaccine production capacity at Bio Farma, Indonesia", Vaccine, vol. 29, no. SUPPL. 1, pp. A22-A25, 2011.

[10] M.M. Cox, P.A. Patriarca, and J. Treanor, "FluBlok, a recombinant hemagglutinin influenza vaccine", Influenza and Other Respiratory Viruses, vol. 2, no. 6, pp. 211219, 2008.

[11] H.P. Sørensen and K.K. Mortensen, "Advanced genetic strategies for recombinant protein expression in Escherichia coli", Journal of Biotechnology, vol. 115, no. 2, pp. 113-128, 2005.

[12] A.S. Farsad, S. Malekzadeh-Shafaroudi, N. Moshtaghi, F. Fotouhi, and S. Zibaee, "Expression of HA1 antigen of $\mathrm{H} 5 \mathrm{~N} 1$ influenza virus as a potent candidate for vaccine in bacterial system", Iranian Jornal of Veterinary Research, vol. 17, no. 4, pp. $237-$ 242, 2016.

[13] G.L. Rosano and E.A. Ceccarelli, "Recombinant protein expression in Escherichia coli: Advances and challenges", Frontiers in Microbiology, vol. 5, no. APR, pp. 1-17, 2014.

[14] A. Sandomenico, J.P. Sivaccumar, and M. Ruvo, "Evolution of escherichia coli expression system in producing antibody recombinant fragments", International Journal of Molecular Sciences, vol. 21, no. 17, pp. 1-39, 2020.

[15] J. Britton, J.N. Smith, C L. Raston, and G.A. Weiss, "Protein Folding Using a Vortex Fluidic Device", Methods in Molecular Biology, vol. 1586, pp. 33-43, 2017.

[16] F. Yu, Y. Li, Y. Guo, L. Wang, J. Yang, et al., "Intranasal vaccination of recombinant $\mathrm{H} 5 \mathrm{~N} 1$ HA1 proteins fused with foldon and $\mathrm{Fc}$ induces strong mucosal immune responses with neutralizing activity: Implication for developing novel mucosal influenza vaccines", Human Vaccines \& Immunotherapeutics, vol. 11, no. 12, pp. 2831-2838, 2015.

[17] A.L. Horwich, "Protein folding in the cell: An inside story", Nature Medicine, vol. 17, no. 10, pp. 1211-1216, 2011.

[18] L. Du, G. Zhao, S. Sun, X. Zhang, X. Zhou, et al., "A critical HA1 neutralizing domain of H5N1 influenza in an optimal conformation induces strong cross-protection", PLoS One, 
vol. 8, no. 1, pp. 1-13, 2013.

[19] S. Khurana, S. Verma, N. Verma, C.J. Crevar, D.M. Carter, et al., "Bacterial HA1 vaccine against pandemic $\mathrm{H} 5 \mathrm{~N} 1$ influenza virus: evidence of oligomerization, hemagglutination, and cross-protective immunity in ferrets", Journal of Virology, vol. 85, no. 3, pp. 1246-1256, 2011.

[20] J.R. Gallagher, D.M. McCraw, U. Torian, N.M. Gulati, M.L. Myers, et al., "Characterization of hemagglutinin antigens on influenza virus and within vaccines using electron microscopy", Vaccines, vol. 6, no. 2, 2018.

[21] G.F. Brooks, K.C. Carroll, J.S. Butel, S.A. Morse, and T.A. Mietzner, Medical Microbiology. 2018.
[22] H. Jeong, H J. Kim, and S.J. Lee, "Complete genome sequence of Escherichia coli strain BL21", Genome Announcements, vol. 3, no. 2, pp. 2015, 2018.

[23] H.P. De Oliveira, M.M. Da Costa, A.H. P. De Oliveira, and M.L.F. Nascimento, "Development of low cost microbial fuel cell based on Escherichia coli", IEEE-NANO 2015 -15th International Conference on Nanotechnology, pp. 940-942, 2015.

[24] F. Angius, O. Ilioaia, A. Amrani, A. Suisse, L. Rosset, et al., "A novel regulation mechanism of the T7 RNA polymerase based expression system improves overproduction and folding of membrane proteins", Scientific Reports, vol. 8, no. 1, pp. 1-11, 2018. 